УДК 811.161.2'373

DOI https://doi.org/10.24919/2308-4863/34-3-22

\author{
Наталія МЕДВЦДЬ, \\ orcid.org/0000-0002-9251-3238 \\ кандидат філологічних наук, \\ доцент кафедри української мови, літератури та методики навчання \\ Глухівського національного педагогічного університету \\ імені Олександра Довженка \\ (Глухів, Сумська область, Україна) Medvedica@ukr.net
}

\title{
ІНДИВІДУАЛЬНО-АВТОРСЬКІ НОВОТВОРИ ВАСИЛЯ ЗЕМЛЯКА
}

\section{Стаття присвячена дослідженню індивідуально-авторських новотворів Василя Земляка. Оказіональна лекси-} ка письменника є иікавим матеріалом із лексико-семантичного, структурно-словотвірного та функиіонального поглядів, оскільки авторські неолексеми в художньому творі посідають помітне місие та засвідчують неповторність індивідуальної мовної майстерності мития слова, впливають на розвиток образної системи художнього мовлення, творення нових номінативних одиниџь та є важливими стилістичними засобами увиразнення мови тощзо. Тому особливого значення набуває мовностилістичний аналіз індивідуально-авторських новотворів.

У статті обтрунтовано актуальність дослідження авторських новотворів у сучасному мовознавстві, подано огляд основних термінопонять, щзо стосуються індивідуально-авторських неологізмів. Проаналізовано семантичні особливості новотворів Василя Земляка, виокремлено найчисленніші тематичні групи, описано номінативну, стилістичну та експресивну функиії інновацій.

Василь Земляк утворює багато індивідуально-авторських неологізмів, близьких до загальновживаних, які є наскрізними і функиіонують у творах із метафорично-символічним значенням. Головна функиія словотворення Василя Земляка -надавати художнього забарвлення контексту, збагачувати лексеми смисловими відтінками, розширювати виражальні можливості загальнонародної мови.

Велика кількість новотворів використовується письменником із метою номінації якогось предмета, поняття чи наміру, оскільки не завжди загальномовні одиниці відповідають прагненням автора образно висловити думку, тому митець створює еквіваленти до наявних узуальних слів.

Оказіональні новотвори Василя Земляка свідчать про плідну праџюю письменника у сфері індивідуального словотворення. Лексичні інновації майстра слова визначаються семантичним багатством, різноманітністю стилістичних, функиіонально-експресивних відтінків значення та використовуються як художні означення до назв предметів, явищз природи тощзо.

Ключові слова: індивідуально-авторський новотвір, оказіоналізм, неолексема, ідіостиль, Василь Земляк.

Nataliia MEDVID, orcid.org/0000-0002-9251-3238

Candidate of Philological Sciences, Associate Professor at the Department of Ukrainian Language, Literature and Teaching Methods Oleksandr Dovzhenko Hlukhiv National Pedagogical University (Hlukhiv, Sumy region, Ukraine) Medvedica@ukr.net

\section{INDIVIDUAL AUTHOR'S LEXICAL INNOVATIONS OF VASYL ZEMLIAK}

The article is devoted to studying the individual authorial innovations of Vasyl Zemliak. Occasional vocabulary of the writer is an interesting material from the lexical-semantic, structural word-forming and functional points of view, as the author's neolexems in the work of art occupy a prominent place and testifies to the uniqueness of individual linguistic skill of the artist; influence the development of important stylistic means of language expression, etc. In this regard, the linguistic and stylistic analysis of individual authorial lexical innovations acquires special significance.

In the article the relevance of the studying the author's lexical innovations in modern linguistics is substantiated, an overview of the basic terms related to the individual authorial neologisms is provided. The semantic features of Vasyl Zemliak's innovations are analysed, the most numerous thematic groups are selected; the nominative, stylistic and expressive functions of lexical innovations are described.

Vasyl Zemliak creates many individual author's neologisms close to the commonly used ones, which are pervasive and function in the works with metaphorical-symbolic meaning. The main function of Vasyl Zemliak's word formation is to give artistic colouring to the context, to enrich linguistic units with semantic nuances, to expand the expressive possibilities of the common popular language. 
A large number of lexical innovations are used by the writer to nominate an object, concept or intention. Due to the fact that the common language units do not always correspond to the author's desire to express an opinion figuratively, so the artist creates equivalents to the already existing usual words.

Occasional innovations of Vasyl Zemliak testify to the fruitful work of the writer in the field of individual word formation. Lexical innovations of the word master are marked by semantic richness, variety of semantic, stylistic, functional-expressive shades of meaning and are used as artistic definitions to the names of objects, natural phenomena and so on.

Key words: individual-author's innovation work, occasionalism, neolexem, idiostyle, Vasyl Zemliak.

Постановка проблеми. Прагнення до оригінального, образного, небуденного вираження думки спонукає митців слова до індивідуальної мовотворчості: «Слово, як основний матеріал творчості, мусить бути завше свіжим і молодим. Таким воно може бути тоді, якщо додержано було трьох моментів: коли воно взято безпосередньо від землі, від народу; коли воно відповідає величі своєї епохи, i, нарешті, коли воно, внаслідок відцвітання старого, створюється як нове, як неологізм» (Герман, 1998: 13).

Результатом вправного оперування словотворчими засобами сучасної української мови є поява лексичної одиниці з оказіональним значенням, яке нефіксується словниками, авиникає впевному контексті та $€$ стилістично вагомим засобом номінації.

На сучасному етапі розвитку лінгвоукраїністики постає потреба теоретичного узагальнення процесів індивідуального словотворення, яке стане можливим лише тоді, коли, по-перше, буде проведено аналіз словотворення сучасних письменників окремо, а також цілих груп авторів у синхронному зіставленні, по-друге, у зіставленні 3 подібними явищами в інших стилях, передусім у розмовному, де найбільше виявляється ця словотвірна тенденція.

В українській літературі середини XX століття помітне місце посідає творчість Василя Земляка (Василя Вацика), талант якого -багата символіка, розлога гіпербола, романтична піднесеність, легка іронія, доброзичливий гумор. Про перші твори Василя Земляка слушно зауважував П. Загребельний: «Уже в цих перших писаннях вгадувався талант своєрідний, неоднорідний, уже в них впали в око деякі елементи, що не вкладалися в прокрустове ложе літературних схем, і ніхто навіть не міг в гадці мати, що це лише перші цеглини до того дивовижного храму, який письменник вибудував у своїй уяві» (Слабошпицький, 1994: 35).

Аналіз досліджень. Оказіональні слова вивчалися в різних аспектах. Значний внесок у теорію оказіонального словотворення зробили О. Габінська, О. Земська, О. Ликов, В. Лопатін, Н. Фельдман та інші. Дослідники визначають способи утворення оказіоналізмів та ступінь продуктивності моделей словотворення. На українському мовному грунті особливості утворення оказіоналізмів вивчали Г. Вокальчук, В. Герман, Л. Павленко, О. Стишов, В. Чабаненко.

У лексикологічному аспекті оказіоналізми на певному синхронному зрізі розглядали О. Александрова, А. Брагіна, О. Габінська. У лексикографічному - Н. Котелова, В. Лопатін, О. Чирков та інші, які порушують питання про створення словників оказіоналізмів. Функціонально-стилістичний аспект оказіональних одиниць вивчали Т. Анісімова, М. Бакіна, О. Ликов, В. Хохлачова.

Актуальність нашого дослідження зумовлена потребою вивчення індивідуально-авторських новотворів Василя Земляка 3 лексико-семантичного, структурно-словотвірного та функціонального поглядів. Саме таке дослідження розкриває роль новотворів як засобів авторського самовираження, що виступають своєрідними формами зв'язку з читачем.

Мета статті - здійснити мовностилістичний аналіз індивідуально-авторських новотворів Василя Земляка.

Виклад основного матеріалу. У мовознавстві проблема вивчення новотворів оказіонального характеру не має остаточного вирішення, на що вказує розбіжність у термінології цих лексичних одиниць: оказіональне слово (Н. Фельдман), авторський неологізм (Р. Кисельова), поетичний неологізм (Л. Загрузна), мовленнєвий новотвір (Г. Клименко), індивідуально-авторський новотвір (Ю. Стехін) та інші, хоча поняття оказіональності з'явилося в науці про мову ще в 1880 році й пов'язане з ім'ям німецького філолога Г. Пауля, який вперше вжив термін «оказіональне значення» і протиставив його узуальному.

Вивчення співвіднесеності та взаємозв'язку канонічних й оказіональних слів - одна з найважливіших проблем мови. У сучасній теорії словотвірної номінації вирішального значення набуває протиставлення потенційних слів як результату узуального словотворення оказіональним словам як наслідкам словотворення неузуального, зумовленого порушеннями норми словотворення. Адже для оказіоналізмів (від лат. occasionalis-«випадковий») -слів, утворених за непродуктивними моделями, вживаними лише в умовах певного контек- 
сту (Ганич, Олійник, 1985: 165), визначальною ознакою $є$ порушення усталеного зразка творення слова. Разом із тим авторські новотвори характеризуються контекстуальною або індивідуальною належністю, а тому більшість із них залишаються за межами мовної системи. Поява новотворів виправдана лише тоді, коли є потреба у виконанні номінативної або художньо-зображальної функції.

Художнє пізнання дійсності стимулює пошук письменником нових мовних засобів, одним 3 яких $\epsilon$ індивідуальне словотворення, в результаті чого поверхнева структура новотвору ускладнюється глибинним переносним значенням.

Василь Земляк утворює багато неолексем, які $\epsilon$ наскрізними і функціонуюють у творах із метафорично-символічним значенням. Отже, головна функція словотворення митця -надавати художнього забарвлення контексту, збагачувати лексеми смисловими відтінками, розширювати виражальні можливості загальнонародної мови.

Велика кількість новотворів використовується письменником із метою номінації якогось предмета, поняття чи наміру, оскільки не завжди загальномовні одиниці відповідають прагненням автора образно висловити думку, тому митець створює еквіваленти до наявних узуальних слів. Прагнення автора дати суб'єктивну оцінку зображуваному сприяє народженню нових ідей, а разом 3 ними і слів. Тому опис чогось нового, що існує лише у вигляді образу, перетворюється на процес позначення цього нового.

Авторські новотвори - це різновид вторинної лексичної номінації. Формуючись, оказіоналізм, на відміну від узуального утворення, не проходить шлях від знаку повідомлення до знаку найменування. Оказіоналізм - це синтез і повідомлення, і найменування, тому оказіональні слова щоразу створюються в процесі комунікації.

У лексиконі Василя Земляка можна виділити такі лексико-семантичні групи новотворів:

1) назви фізичного, фізіологічного стану об'єкта («Дядько, мабуть, узнав Клима Синицю, коли той був словоохочіший, прощав йому нинішню мовчкуватість $і$ дуже пишався тими його вечоровими візитами...» (Земляк, 1984: 15), «Людина обезвіщується в дорозі, і пихатим відчути це навіть корисно, щоб потім не перебільиувати своєї особи, діставшись додому» (Земляк, 1984: 415));

2) назви стану навколишнього середовища ( По озим'ї, ледь над Вавілоном відсльозило стрітення, Сосніна викликав Чубар урядовою й відрядив його на південь, в херсонські степи» (Земляк, 1984: 387));
3) назви осіб ( «Хо-хо, якого зеленушка звабила Мальву з палаиу Родзінських!» (Земляк, 1984: 95));

4) назви засобів пересування («Ще того-таки дня комунар відвіз ї̈ на станиію, на вузькоколійку» (Земляк, 1984: 131));

5) назви рослин та їхніх частин («У Вавілоні такого густоцвіту я не бачив, може, тому, щзо нема там і такого віконечка» (Земляк, 1984: 335)).

Шляхи появи і творення неологізмів визначаються системою словотворчих засобів сучасної української літературної мови, а тому неолексеми виникають за допомогою морфологічних та неморфологічних способів словотворення.

У процесі словотворення Василь Земляк реалізує продуктивні моделі української мови, проте пошук експресивності сприяє використанню малопродуктивних моделей.

Найбільш продуктивним класом новотворів у письменника $є$ іменники, утворені основоскладанням (чорноторопа, світотвір, густоивіт): «Казано ж древніше про тлінність світотвору: "Час іде, а з ним усе стає зужите й нетривале» (Земляк, 1984: 6).

Прості прикметники письменник оновлює суфіксами, префіксами загальномовного вжитку: «Хтось із чоловіків закричав жахним голосом, залементували жінки $і$ кинулися врозтіч, шарахнулись од трактора Павлюкові коні ци пішли носити старого по городах» (Земляк, 1984: 175).

Складні прикметники автор утворює переважно способами осново- та словоскладання: «Це був також високий на зріст, худорлявий, півторарукий чоловік із мужнім смаглявим обличчям $i$ великими добрими очима, в яких промінилася усмішка» (Земляк, 1984: 15); « Де тиняєшся, ледащо? - запитав Фабіян, нащо, певна річ, відповіді не одержав, в очах цуапа був лише пустотливозапобігливий вираз, яким ияап благав не заважати виконувати свій обов 'язок... » (Земляк, 1984: 138).

Письменник використовує складні неолексеми, семантика їх складових частин $є$ досить чіткою, прозорою, зрозумілою і поза контекстом: «Вона поторсала його, але він навіть не повів бровою, так $i$ залишився сидіти, кістляво-холодний» (Земляк, 1984: 197); «Коли ж засіяють дощі й на деякий час усе ніби поглине мстива багнюка, тодi маузер доведеться підняти дещо вище, й та грізна зброя втратить від того, діятиме на місиеву ... публіку не так застрашливо-містично, як зараз, теліпаючись при самій землі» (Земляк, 1984: 105).

У художньому мовленні Василя Земляка префікси $є$ засобом збагачення, поглиблення зображувальної сили дієслів, відображення тонких супроводжувальних відтінків дій, станів. Най- 
більш стилістично маркованими є префіксальні або префіксально-суфіксальні неолексеми: вичумлився, позбратала, довідкрити, опісніє, визула, увікопомнити («Тоді знову вичумлився бубон, пристрасть револючіонерів, а за ним мій батько витяг на кларнеті високе коліно, якого оркестр, розладнаний на весіллях, сягнути не зміг... » (Земляк, 1984: 123)); «...але обидва порізно удавали, що їх мало обходить, звідкіля береться м'ясо, аби тільки воно не скінчилося дочасу, бо тоді знову опісніє шкільна кухня, в якій підгодовували закволілих діток» (Земляк, 1984: 356)).

Дієслівні новотвори в художніх творах Василя Земляка творяться переважно від основ іменників або прикметників. Досить продуктивними $\epsilon$ префіксально-суфіксальні утворення зі значенням «ставати, робитися або робити когось чи щось таким, як предмет чи ознака, названа в мотивуючому слові». Дієслівні новотвори характеризуються експресивністю, вони підкреслюють, увиразнюють ознаку чи предмет, що послужили основою для творення неолексеми: «Ноги в Прісі збуряковіли від холоду, груди ледь вмішувалися в кофтині, обличчя розслаблене $i$ від того все сяяло добротою - була десь на четвертому чи на n'ятому місяиі ...» (Земляк, 1984: 142); «Доки спускався вниз, забоягузів, захитався, та й Купріян їсть мене рудиними очииями, ще не знаючи, для чого я спустився з черешні ...» (Земляк, 1984: 326).

Активними у Василя Земляка є дієприкметникові новотвори 3 префіксами ви-, 3-, за- та суфіксами -іл, -ен: «Заінеєні коні сумно похрумкували обрік в опалках, у такий спосіб рятуючись від морозу» (Земляк, 1984: 212); «А Явтух стоїть на воринах..., легко вловлює хід думок тих двох гультяїв... й хитро посміхається у свої запідлілі вуса, що звисають, як два немічні колоски з однієї соломини» (Земляк, 1984: 56).

У художньому мовленні оказіональні слова виконують різноманітні функції, проте найважливішою $\epsilon$ номінативна. Індивідуально-авторські новотвори використовуються письменником із метою вторинної номінації якогось предмета, поняття, наміру тощо. Адже не завжди загальномовні одиниці відповідають прагненню автора образно висловити думку, тому він створює еквіваленти до наявних узуальних слів.

У художньому мовленні структурно-семантичні особливості неологізмів Василя Земляка впливають на характер породжуваної ними мовленнєвої експресії. У зв'язку з цим розрізняємо утворення, що надають думці колориту ліризму
(«До того ж у віці було кілька щиілинок, і изап мав не лише свіже повітря, а й кілька стежинок визорілого неба» (Земляк, 1984: 87)), пафосу («Дорош устав, обличчя в нього іконописно гарне» (Земляк, 1984: 208)), сарказму («Ніхто не міг передбачити, в тому числі й філософ, щзо Явтушок поплатиться колись за своє дополовинне стовбичення на воринах» (Земляк, 1984: 67)).

Під час створення авторських новотворів на процес номінації впливають прагматичні фактори, які відбивають ставлення мовця до того, що ним називається. У таких випадках оказіоналізми виконують номінативно-оцінну функцію, а в значення оказіонального слова закладається не лише фрагмент дійсності, але й авторська оцінка зображуваного: «Зігерка постояла в дверях, оглянула завечерівців $i$, не знайшовши між ними Сташка, скривджено кинула...» (Земляк, 1984: 388); «Роздаючи коням імена, люди глумились над ними, як зганяли якусь свою потамовану злість на конях» (Земляк, 1984: 475).

Стилістична виразність більшості оказіоналізмів автора пов'язана з відчуттям новизни, що посилюється завдяки можливим асоціативним зіставленням. Наприклад, порівняйте словосполучення штамбові папери, вивіяне зерно і близькі їм за значенням висловлювання в текстах: «Парфуся не старілася ані на один день, штамбові тополі росли довкола хутора як з води, з кожним роком усе надійніше ховали від світу його невеличке изарство...» (Земляк, 1984: 158); «Кволий, вивіяний, в окулярах із тріснутим скельием із величезною драмою в душі - так і не піймав Данька, і тепер може чекативіднього чогозавгодно» (Земляк, 1984:254).

Великою експресивністю позначені синонімічні, тавтологічні за семантикою утворення Василя Земляка: «... і полетять вони засніженим полем назустріч вітрам-вітровинням, $i$ пригорнеться Даринка до Лук'яна та розкаже йому, як хотілося б їй жити на світі...» (Земляк, 1984: 191); «Журба не зупиняв ї̈, над водою здіймався сивий випар, і Мальва плюхнулась туди, як дівчисько, сміялась там, охкала, юхкала, кликала у купіль Журбу» (Земляк, 1984: 320).

Висновки. Отже, індивідуально-авторські новотвори Василя Земляка визначаються семантичним багатством, різноманітністю семантичних, стилістичних, функціонально-експресивних відтінків значення і використовуються як художні означення до назв предметів, явищ природи, завдяки чому автор майстерно досягає персоніфікації, розширює виражальні можливості мови. 


\section{СПИСОК ВИКОРИСТАНИХ ДЖЕРЕЛ}

1. Ганич Д. І., Олійник І. С. Словник лінгвістичних термінів. Київ : Вища школа, 1985. 360 с.

2. Герман В. Неологізми в поезії Івана Драча. Дивослово. 1998. № 5. С. 13-15.

3. Земляк В. С. Твори : в 4-х т. Т. 1. Лебедина зграя. Зелені млини : романи/упоряд. Л. Чубар. Київ : Дніпро, 1984. 619 с.

4. Слабошпицький М. Василь Земляк. Київ, 1994. 149 с.

\section{REFERENCES}

1. Hanych D. I., Oliinyk I. S. Slovnyk linhvistychnykh terminiv. [Dictionary of linguistic terms]. Kyiv : Vyshcha shkola, 1985. 360 p. [in Ukrainian].

2. Herman V. Neolohizmy v poezii Ivana Dracha.[ Neologisms in Ivan Drach’s poetry]. Dyvoslovo.1998. № 5. P. 13-15. [in Ukrainian].

3. Zemliak V.S. Tvory: v 4-kh t. T 1. Lebedyna zghraia. Zelent mlyny [Writings. Swan flock. Green mills]: romany / uporiad. L. Chubar. Kyiv : Dnipro, 1984. 619 p. [in Ukrainian].

4. Slaboshpytskyi M. Vasyl Zemliak. [Vasyl Zemliak]. Kyiv, 1994. 149 p. [in Ukrainian]. 